\title{
Papers on Seediq: Grammar and processing
}

Published online: 27 November 2019

(C) Springer Nature B.V. 2019

The following papers were presented at the Workshop on Seediq and Related Languages: Grammar, Processing, and Revitalization held at the Harvard-Yenching Institute in May 2018. Masatoshi Koizumi of Tohoku University, who organized the workshop, selected a number of papers presented there and submitted them to JEAL for review. He joins the authors in expressing their gratitude to the HarvardYenching Institute for their generous support.

Publisher's Note Springer Nature remains neutral with regard to jurisdictional claims in published maps and institutional affiliations. 